Original research article

\title{
New competencies required for nurses as compared to the national nursing competency standards in Vietnam
}

\author{
Do Thi $\mathrm{Ha}^{1 *}$, Khanitta Nuntaboot ${ }^{2}$ \\ ${ }^{1}$ Pham Ngoc Thach University of Medicine, Faculty of Nursing and Medical Technology, Ho Chi Minh City, Vietnam \\ ${ }^{2}$ Khon Kaen University, Faculty of Nursing, Thailand
}

\begin{abstract}
Background: Nurses' competency is a critical component that governs the quality of healthcare. In the era of the industrial revolution 4.0, the identification of new required competencies for nurses is essential to foster nursing services.

Purpose: The qualitative research aimed to explore new competencies that nurses need - as perceived by nurses and other significant stakeholders - compared to the Core Competencies for Vietnamese Nurses (CCVN) regulated by the Ministry of Health of Vietnam in 2012.

Methods: The research was conducted in Ho Chi Minh City (HCMC), Vietnam, with a purposive sample of thirty-one participants. Data were gathered using in-depth interviews and focus group discussions (FDG). Content analysis was applied to analyze the data.

Findings: The findings revealed that the new competencies required for Vietnamese nurses were: essential attributes of nurses, attitude and values-based nursing care requirements, and transcultural competencies.

Conclusions: Knowledge derived from this study suggested that the innovation of the CCVN should be considered.
\end{abstract}

Keywords: Competency; National competency standards; Nurses; Vietnam

\section{Introduction}

The World Health Organization (2006) confirms that nurses constitute the backbone of the health care system in all countries. Nurses' competency is a critical component that governs the quality of services (ICN, 2002). As a result, deficiencies in nurses' competencies will negatively affect the quality of nursing services. WHO (2016) also calls for all nations to report and implement the plans to improve nurses' competencies. In the era of the industrial revolution 4.0 and globalization, a change in the service paradigm is required, including nursing services and care (Salmond and Echevarria, 2017).

Therefore, new competencies must be integrated into nursing practice to ensure the quality of nursing care. The identification of new competencies that nurses need is essential to foster quality of nursing services.

Several previous studies have identified numerous aspects concerning nursing competencies.

Lenburg (1999) presented numerous needed competencies of nurses in the COPA Model (Competency Outcomes and Performance Assessment). These included skills in assessment, intervention, communication, critical thinking, caring, leadership, and knowledge integration. Kajander-Unkuri et al. (2014) also identified a number of main categories of professional nursing competencies. These were professional values and ethics, nursing and intervention skills, interpersonal and intervention skills, knowledge and cognitive aptitude, assessment skills, improving nursing quality, professional development, leadership, teamwork, and research. In a review article, Fukada (2018) also indicated that nursing competency is often considered as a complex integration of knowledge that includes assessing expertise, skills, values and attitude. According to $\mathrm{Ha}$ and Nuntaboot (2016), competencies of nurses can be defined as a complex combination of needed knowledge, skills, attitude, value-based practice, legal and ethical, as well as cultural competencies.

In the Nurse of the Future Core Competency Model of the Massachusetts Department of Higher Education, ten essential competencies of nurses are applied across all care facilities. These included patient-centered care, professional values, leadership skills, systems-based practice, informatics and technology, communication skills, teamwork and collaboration, safety, quality improvement, and evidence-based practice (Nurse of the Future, 2016). Furthermore, the College of Registered Nurses of British Columbia (CRNBC, 2018) also indicated a framework of competencies among nurses that includes knowledge, skills and abilities such as communication, problem-solving, and decision-making. Tariman et al. (2018) clarified that a nurse's competency includes four dimensions. These are knowledge, attitude, communication, and adaptability.

\footnotetext{
* Author for correspondence: Do Thi Ha, Pham Ngoc Thach University of Medicine, Faculty of Nursing and Medical Technology, Ho Chi Minh City, Vietnam; e-mail: doha@pnt.edu.vn http://doi.org/10.32725/kont.2020.016 
In 2012, Vietnam published the Core Competencies for Vietnamese Nurses (CCVN), which applied for baccalaureate level in nursing. The CCVN consists of three main domains, including (1) Nursing care practice, (2) Management and professional development, and (3) legal and ethical competencies $(\mathrm{MOH}, 2012)$. Although the CCVN has been implemented since 2012, it has not yet been evaluated in relation to whether the criteria of the CCVN are still appropriate in the current context of nursing care in Vietnam.

Understanding the new competencies that nurses need in a specific social and cultural context in Vietnam is necessary. The purpose of this qualitative research is to investigate new competencies required for Vietnamese nurses as perceived by nurses and other significant stakeholders. Deeply understanding the new competencies that nurses need will contribute to the innovation of national nursing competency standards in Vietnam.

\section{Materials and methods}

Qualitative research was applied in order to allow the voices of nurses and other stakeholders in Vietnam to be heard. A variety of participants from different areas of practice were involved in the study, with the assumption that their varying backgrounds would provide a variety of perceptions of Vietnamese nurses' competencies.

This study was conducted in HCMC, Vietnam. The information was elicited from different data collection methodologies. Thirty-one participants, derived from purposive sampling, were involved in the study. These included sixteen nurses who were working in selected clinical facilities in a national general hospital in HCMC. Other participants included three medical doctors (one of whom was the director of clinical department); two medical technicians (one was an anesthetist and another a physiotherapist); three administrators (one of whom was head nurse of the Department of Health of Ho Chi Minh City, Vietnam); three healthcare educators; two patients and two family members.

Ethical approval was obtained from the Khon Kaen University Ethics Committee in Human Research No. HE582133. Participants were informed and clearly explained about the objectives, methodologies, procedures and potential risks, as well as the study's benefits. Informed consent was obtained from each participant before interviewing and FDG. Informants were assured anonymity, confidentiality, and the freedom to withdraw from the study at any time. Their partipation was voluntary.

After obtaining the approval for the study from the institution, the researcher provided clear information about the study to the managers of each selected department. The researcher then contacted potential participants, developed a trusting relationship with them and made appointments for interviews and FDG. Data was collected by in-depth interviews with thirty-one participants and three focus group discussions. Each interview lasted from thirty to ninety minutes, and took place at an appropriate and private place in order to increase the comfort of the interviewee and the overall success of the interview. The three FDGs, each of which were composed of four to six members and lasted from one to two hours, were produced at a hospital meeting room. Both verbal and nonverbal inputs provided by the participants were recognized. Audio tape-recording, detailed note-taking and photography were used during the interviews and FDGs (with permission from the informants).
Content analysis was used to analyze the data. Categories and coding were established. The final emerging themes and categories were established for the Needed Competencies of Nurses (NCN). Each theme and sub theme of the NCN was then compared carefully to the CCVN in order to find out the new points. Each competency of the NCN was analyzed as to whether the CCVN was present, absent, or if the competency was unclear.

\section{Results}

The six essential themes identified as comprising the core components of competencies included: (1) Knowledge, (2) Skills, (3) Attitude and value-based nursing practice, (4) Legal and ethical competencies, (5) Transcultural competencies, and (6) Essential attributes of nurses.

Generally, NCN's competency requirements of nurses resembled the CCVN's. All three of CCVN's competency themes were identified on the NCN. Beside the similarities, there are still large gaps between the contents of the NCN and CCVN. The NCN focused not only on the three domains included in the CCVN, but also on other new points, including (1) Essential attributes of nurses, (2) Attitude and value-based nursing practice, (3) Transcultural competencies.

\section{Essential attributes among nurses}

As perceived by the participants (in both in-depth interviews and FDG), the essential attributes among nurses were seen as the foremost and most special domain of nurses' competencies. Good qualities of a nurse were the indispensable catalysts for holding all the elements (such as knowledge and skills) together to create a competent nurse. These characteristics seem to be inherent traits that a nurse must intrinsically possess and that cannot be obtained in the same manner as knowledge or skills. As indicated, essential attributes among nurses included several virtues such as good qualities, inherent characteristics, and professional appearance. Good professional appearance among nurses included healthiness, fresh and tidy uniforms, unhurried working style, positive attitude during communication with others, compassionate facial emotion, remaining calm, being gentle, and confidence.

The participants indicated that competent nurses who possessed inherent worthy qualities seemed to have a certain spirit and capability that enabled them to go above and beyond in their roles as healthcare providers. These qualities also empowered competent nurses to perform all tasks or duties, regardless of the conditions, for example personal or teamwork issues, emergencies, interruptions, or other difficult circumstances.

\section{Attitude and value-based nursing practice}

According to the participants in the research, nurses must have a very positive attitude towards the nursing profession and nursing care. Nurses establish a foundation for practice through the acquisition of knowledge and skills. However, positive attitude of a nurse is the most important element that decides the quality of nursing services. Positive attitude and value-based nursing practice were identified as loving, caring, and providing nursing care in a respectful manner. Loving and caring were difficult and abstract concepts. The participants stated that loving can be seen as the center of moral engagement between nurses and clients, while caring is a feeling of concern and empathy for clients. These were the most important elements in what nurses do for clients as human beings. 
Furthermore, respectful communication with clients or implementing nursing care based on humanistic values, integrity and dignity, were vital concerns and expectations of all the research participants (in both in-depth interviews and FDG).

\section{Transcultural competencies}

The participants recognized that, as we move into a more diversified world, transcultural competencies of nurses play a very important role in effectively caring for clients. Nurses who practice in clinical settings are required to be sensitive and respectful to diverse cultures. The participants involved in the FDG confirmed that when taking care of clients, nurses need to apply different cultural knowledge and cultural sensitivity skills in fulfilling their tasks - in order to respect the beliefs, norms and practice of clients. At the same time, there is a vision of a common humanity. The recent trend is to try to preserve these cultures, rather than to assimilate them completely. Hence a competent nurse needs to think more deeply and act according to clients' beliefs and norms. These expectations were shared by both individual interview participants and FDG's.

In summary, there are three main themes of the NCN that differ from the CCVN's. Firstly, essential attributes of nurses, including good qualities, professional appearance, and inherent characteristics among nurses were identified as needed requirements to become a competent nurse. Secondly, nurses must have a positive attitude toward the nursing profession and nursing care, high commitment to the tasks, respect clients and provide nursing care based on humanistic values, integrity and dignity. Furthermore, as we are living in an era of constant change and diverse cultures, all of the participants in the study strongly expressed the view that today's nurses are expected to be competent, sensitive and respectful of the diversity of cultures.

\section{Discussion}

The competencies required for nurses in Vietnam included: essential attributes among nurses, knowledge, skills, attitudes and value-based nursing care, legal and ethical capabilities, and transcultural competencies. The findings generated in this study were in line with the features of nursing capabilities as set out by the International Council of Nurses (ICN, 2008; 2009), the American Association of Colleges of Nursing (AACN, 2008), the Nurse of the Future Core Competency Model of the Massachusetts Department of Higher Education
(MDHE, 2016) and other previous studies (Benner, 1984; Ha and Nuntaboot, 2016; Kajander-Unkuri et al., 2014).

In a review study, Fukada (2018) also indicated that nursing competency is often considered as a complex integration of knowledge that includes the assessment of expertise, skills, values and attitude. Nurses are also required to apply their knowledge, skills and innate personalities to each situation in nursing practice. According to Ray (2016), in today's complex world, individuals must transcend their own culture-bound assumptions. "The human person is a center of consciousness, which is capable of infinite extension, and as it grows it becomes more and more integrated with the whole complex of persons who make up humanity." We must all move toward growth-producing intercultural transcultural relationships. For the most part, respect for ways of life that serve the good of people in a complex and dynamic world have become the goal.

Besides the similarities, there are still big gaps between the contents of the NCN and CCVN. The NCN includes not only three domains of the CCVN, but also other new aspects such as: essential attributes of nurses, attitude, values-based nursing practice, and transcultural competencies. The NCN would be valuable for the innovation of the competency standards for Vietnamese nurses, and for the development of appropriate strategies to improve competencies for nurses in Vietnam.

\section{Conclusions}

Identifying the new competencies required for nurses in today's complex world is essential for effective nursing care. This is one of the first studies to deal with competencies among Vietnamese nurses. The findings from this study provide preliminary evidence to help further the understanding of the needed competencies of nurses in particular social-political and cultural contexts in Vietnam. It could initiate further researches concerning competencies of nurses in Vietnam, and discussions about the innovation of the national competencies standards.

\section{Acknowledgements}

The researchers appreciate all of the members who gave their time so graciously in order to participate in the study and any person who facilitated the work.

\section{Conflict of interests}

The authors have no conflict of interests to declare.

\section{Nové kvalifikace potřebné pro zdravotní sestry ve srovnání se současnými kvalifikačními standardy ve Vietnamu}

\section{Souhrn}

Úvod: Kvalifikace zdravotních sester je kritickým komponentem, který určuje kvalitu zdravotní péče. Identifikování potřebných nových kvalifikací je nutné pro rozvoj ošetřovatelských služeb.

Cíl: Kvalitativní výzkum byl zaměřen na prozkoumání nových kvalifikací, které zdravotní sestry potřebují - dle jejich vlastního názoru a i názoru jiných zainteresovaných stran - ve srovnání se současnými kvalifikačními standardy (Core Competencies for Vietnamese Nurses - CCVN) vydanými vietnamským ministerstvem zdravotnictví v roce 2012.

Metodika: Výzkum byl proveden ve Vietnamu v Ho Či Minově Městě na vzorku 31 účastníků. Sběr dat probíhal pomocí hloubkových interview a skupinových diskusí. Data byla vyhodnocena pomocí obsahové analýzy.

Výsledky: Výsledky ukázaly, že nové kompetence požadované pro vietnamské zdravotní sestry jsou základem pro ošetřovatelskou péči, založenou na postojích, hodnotách a transkulturních kompetencích.

Závěr: Poznatky získané touto studií ukazují na to, že kvalifikační standardy CCVN by bylo vhodné modernizovat. 


\section{References}

1. American Association of Colleges of Nursing [AACN] (2008). The Essentials of Baccalaureate Education for Professional Nursing Practice. [online] [cit. 2019-09-23]. Available from: http://www.aacn.nche.edu/education-resources/ BaccEssentials08.pdf

2. Benner P (1984). From novice to expert: Excellence and power in clinical nursing practice. Menlo Park, CA: Addison-Wesley, pp. 13-34.

3. College of Registered Nurses of British Columbia [CRNBC] (2018). Applying the Competencies Required for Nurse Practitioners in British Columbia. [online] [cit. 2019-09-23]. Available from: https://www.bccnp.ca/becoming_a_nurse/ Documents/NP_applying_completencies_440PLAR.pdf

4. Ha DT, Nuntaboot K (2016). Actual Nursing Competency among Nurses in Hospital in Vietnam. World Academy of Science, Engineering and Technology International Journal of Nursing and Health Sciences 10(3): 1002-1009. DOI: 10.5281/ zenodo. 1125365 .

5. Fukada M (2018). Nursing Competency: Definition, Structure and Development. Yonago Acta Med 61(1): 1-7. PMC5871720.

6. International Council of Nurses [ICN] (2002). [online] [cit. 2019-09-23]. Available from: http://www.icn.ch/who-we-are/ icn-definition-of-nursing/

7. International Council of Nurses [ICN] (2008). Nursing Care Continuum Framework and Competencies. [online] [cit. 2019-09-18]. Available from: https://siga-fsia.ch/files/user upload/07_ICN_Nursing_Care_Continuum_Framework_and_ Competencies.pdf

8. International Council of Nurses [ICN] (2009). ICN Framework of Competencies for the Nurse Specialist. [online] [cit. 2019-0918]. Available from: https://siga-fsia.ch/files/user_upload/08_ ICN_Framework_for_the_nurse_specialist.pdf.
9. Kajander-Unkuri S, Meretoja R, Katajisto J, Saarikoski M, Salminen L, Suhonen R, Leino-Kilpi H (2014). Self-assessed level of competence of graduating nursing students and factors related to it. Nurse Educ Today 34(5): 795-801. DOI: 10.1016/j. nedt.2013.08.009.

10. Lenburg CB (1999). The framework, concepts and methods of the competency outcomes and performance assessment (COPA) model. Online Journal of Issues in Nursing 4(2): 1-12.

11. Massachusetts Department of Higher Education [MDHE] (2016). The Future Nursing Core Competencies. [online] [cit. 2019-09-18]. Available from: http://www.mass.edu/nahi/ documents/NOFRNCompetencies_updated_March2016.pdf.

12. Ministry of Health of Vietnam [MOH] (2012). Core Competency for Vietnamese Nurses. Ha Noi, Vietnam.

13. Ray MA (2016). Transcultural caring dynamics in nursing and health care. Philadelphia; F. A. Davis Company.

14. Salmond SW, Echevarria M (2017). Healthcare Transformation and Changing Roles for Nursing. Orthop Nurs 36(1): 12-25. DOI: 10.1097/NOR.0000000000000308.

15. Tariman JD, Katz P, Bishop-Royse J, Hartle L, Szubski KL, Enecio T, et al. (2018). Role competency scale on shared decision-making nurses: Development and psychometric properties. SAGE Open Med 6: 1-10. DOI: $10.1177 / 2050312118807614$

16. World Health Organization [WHO] (2006). The world health report: Working together for health. Geneva, Switzerland: World Health Organization.

17. World Health Organization [WHO] (2016). Global strategic directions for strengthening nursing and midwifery 2016-2020. [online] [cit. 2019-09-23]. Available from: https://www.who.int/ hrh/nursing_midwifery/global-strategic-midwifery2016-2020. pdf?ua $=1$. WHO Library Cataloguing-in-Publication Data 